\title{
Boron geochemistry of European agricultural soil
}

\author{
PHILIPPE NEGREL ${ }^{1}$, ANNA LADENBERGER ${ }^{2}$, CLEMENS \\ REIMANN $^{3}$, ALECOS DEMETRIADES ${ }^{4}$, MANFRED DR. \\ BIRKE $^{5}$ AND MARTIYA SADEGHI ${ }^{2}$ \\ ${ }^{1}$ BRGM, France \\ ${ }^{2}$ Geological Survey of Sweden \\ ${ }^{3}$ Geological Survey of Norway \\ ${ }^{4}$ IUGS Commission on Global Geochemical Baselines \\ ${ }^{5}$ Federal Institute for Geosciences and Natural Resources \\ Presenting Author: p.negrel@brgm.fr
}

Boron about a century ago was recognised as an essential element for normal growth of plants and for terrestrial organisms. Limitations for plant development are recognised in agricultural systems, particularly in highly weathered soil. Boron is rarely analysed in whole rock or soil analysis, as it requires specific analytical techniques and is, thus, often determined, after partial extraction (aqua regia or $\mathrm{Ca}-\mathrm{Cl}$ ), usually on a limited number of samples. Many more questions than answers exist about $\mathrm{B}$ environmental behaviour.

We present $\mathrm{B}$ concentrations in samples of agricultural soil samples in Europe (33 countries, 5.6 million $\mathrm{km}^{2}$ ) collected during the GEMAS (GEochemical Mapping of Agricultural and grazing land Soil) continental-scale project using concentrations determined by aqua regia extraction. The B range in GEMAS soil is $0.5-49 \mathrm{mg} / \mathrm{kg}$ (median $2.42 \mathrm{mg} / \mathrm{kg}, \mathrm{n}=2108$ ), lower than the range observed in selected FOREGS topsoil samples (total B, 3-164 mg/kg, median $39.9 \mathrm{mg} / \mathrm{kg}, \mathrm{n}=198$ ), while the total $\mathrm{B}$ estimate for the Upper Continental Crust is in the range 17-47 $\mathrm{mg} / \mathrm{kg}$. Mapping of $\mathrm{B}$ concentration in soil shows low concentrations over granite and high concentrations over limestone and volcanic areas. Our investigation comparing partial extraction (GEMAS) and total concentration (FOREGS) at the European continental-scale provide a new vision of $\mathrm{B}$ behaviour, which can be further used for investigating $B$ beneficial and adverse health effects. 